\title{
Analysis of Talent Training Scheme for Electrical and Mechanical Professional of Higher Vocational Colleges
}

\author{
Miao Shang ${ }^{1, \mathrm{a}^{*}}$ and Jiabin $\mathrm{Li}^{1, \mathrm{~b}}$ \\ ${ }^{1}$ College of Mechanical Engineering, Xijing University, Xi'an, China \\ a445700839@qq.com, b316404239@qq.com
}

\begin{abstract}
Keywords: Mechanical and electrical professional; Talent training; Higher education; Work-integrated learning; Enterprise practice
\end{abstract}

\begin{abstract}
At present our country has built the world's largest education system, and our country implements the big powers to the human resources from people. Our country needs from human resource country to strong human resources. The mechanical and electrical professional training mode of higher vocational colleges were introduced in this article; The talents cultivation goals of electrical and mechanical professional were orientation; The direction of the electrical and mechanical professional talents is illustrated; The electrical and mechanical professional curriculum is summarized. Finally draws the following conclusions: the cultivation of the electrical and mechanical professional talents in higher vocational colleges is dependent on the work-integrated learning, the cultivation of the electrical and mechanical professional talents in higher vocational colleges need to enterprise's practical conditions, the cultivation of higher vocational college of mechanical and electronic professional talents need to all-round development. The investigation and analysis of mechanical and electrical professional talent training scheme in higher vocational colleges to cultivate the consultation has important guiding significance.
\end{abstract}

\section{Introduction}

Schools to implement personnel training the talent training scheme works fundamental guidance documents, the document is a school of the concentrated reflection of education ideas and education concept, the document is the personnel training target, training mode and training process and the way of total design, to ensure the quality of teaching and talent training specifications, improve the quality of talent training has important guiding role [1].

Higher vocational college of electrical and mechanical professional talents cultivation model need training mode of work-integrated learning, training condition of higher vocational education needs depends on the complementary between colleges, cultivate moral, intellectual, physical, all-round development of the compound talents [2]. Higher vocational electrical and mechanical professional talents needs must be the basic theory of knowledge, professional knowledge, entrepreneurial spirit and good professional ethics. Higher vocational electrical and mechanical professional talents need needs certain theoretical basis, need to master the professional technology and maintenance technology, the need to manage a line technology applied talents.

\section{Electrical and Mechanical Professional Talents Cultivation Target Positioning}

Higher vocational colleges in order to study the mechanical and electrical kind of professional personnel training mode and curriculum system of the status, analysis of higher vocational college of mechanical and electronic professional system there may be a problem, the author on the basis of field investigation, summing up the conclusion of many are common. Based on the northwestern region of the local economy difference and focused on the different industry development goals, local vocational education development direction, there is a big difference [3]. Its training goal has obvious regional and industrial demand, coupled with the vocational college teaching resources in reserve, financial investment, and there are many differences between teachers, etc, so all the training objectives of higher 
vocational college of mechanical and electronic professional there are significant differences [4]. Mainly include two aspects, one is to cultivate application-oriented mechanical and electronic products design and manufacture of skills; The second is to develop manufacturing oriented value chain of high-end talent.

Mechanical and electrical products design and manufacturing skills applied talents. Machinery specialized in the professional background of advanced manufacturing, to impart knowledge, combining ability training and quality education, basic training to master modern mechanical design and manufacturing theory knowledge, engaged in modern mechanical and electronic products processing, equipment design and manufacture, control and management of the senior specialized talents [5].

Our country needs from human resource country to strong human resources. This professional mechanical and electrical manufacturing, oriented training has adapted to the cultural level and quality, good professional ethics and innovation spirit, to master the application technology, machinery manufacturing with operation, debugging and maintenance of mechanical and electrical equipment and machinery and technology, the assembly design, for production line has a strong ability to advanced applied technology talents [6]. This professional training has a certain political quality and professional ethics quality, master modern machinery and electronic products design, manufacture basic knowledge and skills, be able to use mechanical and electrical manufacturing theory is engaged in the mechanical product design, manufacture, maintenance and related technical and management work of higher technology applied talents.

(2) Develop manufacturing oriented value chain of high-end talent. This professional training support the party's basic line, to adapt to the production, construction, management, service the first line of beauty, intelligence and physique full scale development the high quality, highly skilled, innovative talents; Students should master mainly engaged in the professional practice of basic skills and basic skills, has the good professional ethics and professional spirit, have the ability of sustainable development. Mastered the basic mechanical design and manufacturing of professional theory, professional knowledge, professional skills and professional technical application ability, can in mechanical manufacturing field in the mechanical product design and manufacturing, numerical control machine operation, programming, machine set the operation, maintenance and management of high-quality skilled personnel. This major mainly for machinery manufacturing technology application in the field of design, manufacture, management, service and other frontline positions, cultivating ability, high quality, which will understand the technology, management, social satisfaction of high skilled talents. This professional training to master modern machinery manufacturing and white dynamic basic theoretical knowledge, modern machinery a device control and technology management, and has strong quality professionals with comprehensive professional ability.

\section{Direction of Electrical and Mechanical Professional Talents}

From the investigation of the higher vocational college of mechanical and electronic professional personnel training specification, its contents are specific [7]. From the basic quality to knowledge, from knowledge to the job technology, from the knowledge structure to structure, from professional basis to professional technology, there are clear requirements. Mechanical and electronic products design and manufacture of skills applied talents in higher vocational colleges, pay more attention to the students' ability of first-line operation requirements [8]. Professional positioning in the major technology intensive enterprises oriented production line is engaged in mechanical and electrical products manufacturing installation, debugging work, target is very clear. Develop manufacturing oriented value chain of high-end talent, pay more attention to the design, process management, comprehensive quality and ability of machining operations. Emphasizes the students can in mechanical manufacturing field in the mechanical product design and manufacturing, numerical control machine operation, programming, mechanical equipment operation, maintenance and management. The cultivation of the electrical and mechanical professional talents requires knowledge structure, ability structure, need professional knowledge, professional quality, job ability and social and so on. 


\section{Course Structure Settings of Mechanical and Electrical Professional}

Type of Course. Higher vocational colleges based on the types of courses in electrical and mechanical professional talent training scheme has carried on the statistical analysis, summarized as similar course type category. Theory course can be divided into four categories: comprehensive quality courses, specialized core courses, direction, courses and professional courses [9]. Through the four categories of curriculum setup, it can be seen that the proportion of four major categories of all course that comprehensive quality courses, specialized core curriculum, direction of courses and professional courses accounted for $32 \%, 48 \%, 10 \%, 10 \%$.

Comprehensive quality module based on the general course makes the students as "social person", "professional" social quality and professional quality, graduates as "social person" and "professional" basic quality requirements; Specialized core curriculum modules and direction, according to the professional group of professional quality, professional quality and professional skills requirements, considering the professional flow and the need of professional post professional quality promotion, outstanding students to adapt to the group professional skill ability, according to the basic requirement of professional knowledge, ability and skills to set up the course. Professional development module of the course improve the students' knowledge structure, and the course expand the students' knowledge and set course. Practical courses are divided into basic skills module, professional skills, vocational skills module and integrated skills module. The proportion were $18 \%, 22 \%, 23 \%, 37 \%$. This course type is set according to the characteristics of the courses of the course as a full set of technology, and the course content is designed according to the technical system. Break the traditional public basic course, professional basic course and specialized course, practical skills training mode, conform to the mainstream in the development of vocational education. But as the enterprise of mechanical design and manufacturing of professional talents cultivation level increasing, but also it need to build a more rational, perfect and multiple blended class hierarchy [10].

Hours and Credit. Through the statistical analysis of mechanical and electrical professional teaching process in higher vocational colleges, the general quality course in higher vocational college of mechanical and electronic modules mainly includes the course of thought morals tutelage and legal foundation, an introduction to MAO zedong thought, deng xiaoping theory and "three represents" important thought introduction, situation and policy, sports, English, advanced mathematics, information technology, career planning and other public required course. Professional core courses module mainly includes the mechanical drawing, electrician and electronic technology, engineering mechanics, engineering materials and heat treatment, interchangeability and measuring technology, mechanical design basis, hydraulic and pneumatic technology, machine tool electrical control and PLC and single-chip microcomputer principle and application of professional basic course. Professional direction course module mainly includes the machinery manufacturing technology, principles of metal cutting and cutting tools, machine tool fixture design, machine tool equipment and design, professional required courses, such as $\mathrm{CAD} / \mathrm{CAM}$. Professional development courses module mainly contains, metal cutting machine tools and CNC machine tools and programming design, CAXA, Mastercam, Turner technology, millers technology courses, etc. Due to mechanical and electrical specialty is an application of technical, project practice is the key to the talent training scheme and the basic skills of the practice teaching module mainly includes the entrance and the national defense education, AutoCAD training, English training, drawings, parts of surveying and mapping course design, electrician electrical training, etc. Professional skills module mainly include machine design, mechanical dismantling internship, fixture design, process planning such as specified. Vocational skills module mainly include fitter practice, Turner practice, nc machining, welding training, etc. Comprehensive skills module mainly includes the graduation practice, graduation design and graduation education.

\section{Conclusions}

Mechanical and electrical specialty in higher vocational colleges is universal. Due to the specific situation of the higher vocational colleges different, mechanical and electrical professional talent training 
scheme also have very big difference. In general, mechanical and electrical professional can be divided into two categories, one kind is partial mechanical direction, one kind is partial electrical direction, machine and electricity is organic to combine, however, very few. The mechanical and electrical professional training mode of Higher vocational colleges were introduced in this article; The talents cultivation goals of electrical and mechanical professional were orientation; The direction of the electrical and mechanical professional talents is illustrated; The electrical and mechanical professional curriculum is summarized. Finally draws the following conclusions: the cultivation of the electrical and mechanical professional talents in higher vocational colleges is dependent on the work-integrated learning, the cultivation of the electrical and mechanical professional talents in higher vocational colleges need to enterprise's practical conditions, the cultivation of higher vocational college of mechanical and electronic professional talents need to all-round development. The investigation and analysis of mechanical and electrical professional talent training scheme in higher vocational colleges to cultivate the consultation has important guiding significance.

\section{Acknowledgements}

The research work is supported by XiJing University Scientific research fund No.XJ150212.

\section{References}

[1] J.B.Wang, H.T.Yang:New Field of Overseas Investment-New Trend of Transnational Higher Education (DongYue Review, China, 2012)

[2] H.Y.Liu: UDP Proportion Higher Education and Social Policy Research (China, 2012), P. 27.

[3] Chun Zhou. Jiang Machinery Innovation Ability Structure of System Analysis of Higher Vocational Students. (Ph.D., Education and career, China 2011), P.56.

[4] Xiang wei Liu: Based on Working Process of Development of Higher Vocational Machinery Manufacturing Professional Curriculum Strategy. (Ph.D., Education and career, China 2011), p.138.

[5] Jun Ma: Study on Curriculum System of Higher Vocational Project (Beijing university of science and technology press, China 2011), p.25.

[6] WenFeng Zhen. Specialized Courses for Higher Vocational Colleges Management Development Present Situation Research (Xi 'an, 2011).Vol.1,p.14.

[7] Benoit Minogue: Higher Education Spending and Output-Complexity of Relationship, Peking University Education review (Xi 'an, 2013), Vol. 2, p. 60.

[8] Xun Deng: Our Country's Higher Vocational Education Curriculum System Constructio ( Xi 'an, 2010). Vol.2.

[9] Boqing Wang:Chinese University Students' Employment Report (Social sciences academic press,China 2012). Vol.1, p. 46.

[10] J.B.Wang, H.T.Yang: New Field of Overseas Investment-New Trend of Transnational Higher Education (China, 2012). 